\title{
Finding Martyrs at Home?: Jesuit Attempts at Redefining Martyrdom in the Seventeenth Century and Their Censure
}

\author{
Jean-Pascal Gay \\ Faculty of Theology, Institut de Recherche Religions, Spiritualités, \\ Cultures, Sociétés; Université catholique de Louvain, Louvain-la-Neuve, \\ Belgium \\ jpgay@uclouvain.be
}

\begin{abstract}
Pope Francis's recent recognition of the death of several priests active in Guatemala in the 198 os as martyrdom has reminded the public of a long-term hesitation within Catholicism as to the boundaries of martyrdom. Key aspects of the history of this hesitation played out in the seventeenth century. Several religious orders-most prominently the Jesuits - argued for a redefinition of martyrdom that would include the so-called "martyrdom of charity" (i.e. the death of those who had imperiled their lives to care for the sick). Among the theologians that entered the fray to advocate for such a redefinition, the most prominent is certainly Theophile Raynaud (the "new Bellarmine" of the mid seventeenth century) whose De martyrio per pestem was censured with other texts that promoted the same position, when the Inquisition decided to take a stand against the campaign for the redefinition of martyrdom. By studying Raynaud's and other treatises, as well as their censure, this paper will try to assess the significance of this debate for Jesuit history and that of early modern Catholicism. It will try and show how it connected with the theological controversies of the time but also how it pertained to an issue within the order, namely that of the hierarchy of ministries that sometimes weighed on how the order operated, particularly in Europe.
\end{abstract}

\section{Keywords}

martyrdom - martyrdom of charity - censure - Theophile Raynaud - theological controversies - Pope Francis

(C) JEAN-PASCAL GAY, 2022 | DOI:10.1163/22141332-09010002

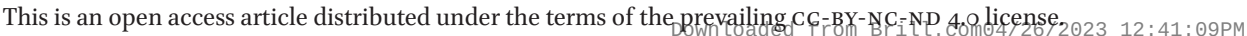


Pope Francis recently recognized several priests who were killed in Guatemala in the 1980 s as martyrs, reminding the public of long-standing debates within Catholicism on the shifting boundaries of martyrdom. The idea that putting one's life at risk out of charity can be considered worthy of martyrdom appears, at first glance, to be fairly new to the Catholic Church. Pope Paul vi (r.1963-78) used the expression when he beatified the Franciscan Maksymilian Kolbe (1894-1941), who died at Auschwitz when he volunteered to take the place of a man who would have been executed as one of the group of ten who were to starve to death to set an example after one prisoner escaped. In the context of liberation theology and political violence in South America, the idea that dying in the service of a community can fit in the religious narrative of martyrdom takes on more political overtones. ${ }^{1}$

What has not yet been noted is that there is a specific Jesuit background to contemporary discussions of a "martyrdom of charity." It is perhaps telling that it is the first Jesuit pope who has altered the Normae servandae in inquisitionibus ab Episcopifacendis in causis Sanctorum (Norms to be observed in inquiries made by bishops in the causes of saints) to include recognition of "offerings of life" out of love for God and one's neighbor in particularly dire circumstances. ${ }^{2}$ Immediately in the wake of Kolbe's canonization, Karl Rahner (1904-84), one of the most famous Jesuit theologians of his time, was the most prominent champion of a broadening of the definition of martyrdom. ${ }^{3}$ This Jesuit background is also an early modern background. In the seventeenth century, several religious orders - the Jesuits in particular-advocated such a redefinition of martyrdom. The Jesuits continued to maintain a corporate commitment to the "works of mercy," although this fluctuated over time and space. ${ }^{4}$ There were thus particular religious and ecclesial stakes in their advocacy for the recognition of a martyrdom of charity. While the Roman Curia refused to accept such an evolution and censured several texts and treatises that tried to promote it, a similar tradition of interpreting holiness seems to have survived in

1 On the contemporary discussion, see Anna Lisa Peterson, Martyrdom and the Politics of Religion: Progressive Catholicism in El Salvador's Civil War (Albany: Suny Press, 1997), 93-96. On the influence of liberation theology, see Rubén Rosario Rodríguez, Christian Martyr: A Comparative Theology with Judaism and Islam (Cambridge: Cambridge University Press, 2017).

2 Motu proprio Maiorem hac dilectionem, July 11, 2017. See http://w2.vatican.va/content/ francesco/en/motu_proprio/documents/papa-francesco-motu-proprio_20170711_maioremhac-dilectionem.html (accessed October 14, 2021).

3 Karl Rahner, "Dimensions of Martyrdom: A Plea for the Broadening of a Classical Concept," Concilium 18 (1983): 9-11.

4 John W. O'Malley, The First Jesuits (Cambridge, MA: Harvard University Press, 1993), 165-99. 
some religious orders and other Catholic communities, before resurfacing in the late twentieth century.

Among the theologians who entered the fray to campaign for this redefinition, the most prominent was, without a doubt, Theophile Raynaud (c.15831663). While Raynaud is but little remembered today and was later dismissed as an odd figure in the history of Catholic theology, it is difficult to overstate his importance for Europe's theological scene in the mid-seventeenth century. ${ }^{5}$ In 163o, he published a theological dissertation, De martyrio per pestem (Of martyrdom by plague), ${ }^{6}$ in which he argued that those who risk their lives taking care of the sick, and die as a result, could and should be deemed "vere Christi martyres." In 1646, the Congregation of the Holy Office prohibited this dissertation from reading, along with several other texts in a similar vein. The Inquisition clearly decided to take a stand against the campaign to redefine martyrdom. The censure of Raynaud's theological defense of this redefinition was central to the Inquisition's effort to put an end to the campaign. Raynaud fiercely debated the prohibition and a corrected version of his book would finally be taken off the Index, just as the Jesuits were promoting the publication of Raynaud's Opera omnia.

By studying Raynaud's treaty, its censure, and the challenges to this censure, this paper will try to assess the significance of this debate for Jesuit history and that of early modern Catholicism. It will try to show how it related to the theological controversies of the time, but also how it pertained to an issue within the order, namely that of the hierarchy of ministries that sometimes heavily affected how the order operated, particularly in Europe.

\section{The De martyrio per pestem: Circumstances and Content}

While Raynaud's dissertation De martyrio per pestem shows great originality, its purpose may have been narrower than appears at first glance. It figured in Raynaud's hagiological activity and his contribution to what Stéphane Van Damme has characterized as the naturalization of the Society of Jesus in the

5 On Raynaud and his importance for a cultural history of early modern theology, see Jean-Pascal Gay, Le dernier théologien?: Théophile Raynaud, histoire d'une obsolescence (Paris: Beauchesne, 2018). On Raynaud and his philosophy, see Jacob Schmutz, "Théophile Raynaud," in Dictionary of Seventeenth-Century French Philosophers, ed. Luc Foisneau, 2 vols. (London: Thoemmes, 2008), 2:1052-57.

6 Théophile Raynaud, De martyrio per pestem: Disquisitio theologica (Lyons: Iacobus Cardon, 1630), hereafter De martyrio. 
city of Lyons. ${ }^{7}$ From 1628 to 1629 , an acute case of the plague afflicted the city. Several Jesuits committed themselves to alleviating the suffering of the sick, some of them contracting the disease and dying. ${ }^{8}$ The catalog of the province for 1630 registered 46 deaths that year, of which 18 in Lyons; that of 1631,32 deaths "among which several were taken by the plague or by ministering to those suffering from the plague."

The hypothesis of a "martyrdom of charity" allowed Raynaud to paint Lyons as a godly city and the Jesuits as central to that godliness. A dedicated hagiologist, Raynaud composed an Indiculus Sanctorum Lugdunensium (Small index of the saints of Lyons) in the aftermath of the plague ${ }^{10}$ that a fellow Jesuit almost immediately translated into French. ${ }^{11}$ While predominantly a historical work, the Indiculus concludes with a Mantissa de piis quibusdam Ludgunensibus non vindicatis, which details the lives of recent models of extraordinary religious virtue, including, but not limited to, several Jesuits. Raynaud mentioned one who had died taking care of the sick during the plague, François Bouton $(1578-1628) .{ }^{12}$

The publication of the De martyrio per pestem was therefore part of the Jesuits' effort to turn the 1628-29 plague into a religious event that showcased their own devotion to the common good as well as to the city. In 1629, Jean Grillot (1588-47) published his Lyon affligé de contagion, ${ }^{13}$ an account of the epidemic, including a specific chapter on the charity of "men religious and other ecclesiastics." ${ }^{14}$ Grillot quotes Raynaud's praise of François Bouton and expands on it. Bouton, he writes, "gloriously joined the four Palms that the Church reveres separately in several of the number of the Blessed"; he "died a Confessor, because he had been held in prison for a long time by the Turks (enemies of our holy faith) [...]; he is a Doctor, since he taught the study of

7 Stéphane Van Damme, Le Temple de la Sagesse: Savoirs, écritures, sociabilité urbaine (Lyon XVII ${ }^{e}-X V I I I^{e}$ siècles) (Paris: Éditions de l'E HESs, 2005).

8 On the 1628 plague, see Yann Lignereux, Lyon et le Roi: De la "bonne ville" à l'absolutisme municipal (1594-1654) (Seyssel : Champ Vallon, 2003), 697-701.

9 ARSI, Ludg. 14.

10 Indiculus Sanctorum Lugdunensium concinnatus a Theophilo Raynaudo [...] Addita Mantissa de piis quibusdam Lugdunensibus non vindicatis (Lyon: Claudius Landry, 1629). Faculties are from January 1629, the approbation from March.

$11 \quad$ Les Saincts de Lyon du R. P. Théophile Raynaud professeur en Théologie de la Compagnie de Jésus, traduicts du latin par un Religieux de la mesme Compagnie (Lyon: Esprit Scot, 1629).

12 Les Saincts de Lyon du R. P. Théophile Raynaud, 402-15.

13 Jean Grillot, Lyon affligé de contagion ou narré de qui s'est passé de plus mémorable en ceste Ville, depuis le mois d'Aoust de l'an 1628, iusques au mois d'Octobre de l'an 1629 (Lyon: François de la Bottiere, 1629).

14 Grillot, Lyon affligé, 87-103. 
Holy Scriptures with great satisfaction for a long time [...]; he passed away with the flower of his virginity [...]; to these glorious titles he finally added that of Martyr, since he died in service of those afflicted by the plague." Bouton, Grillot writes, even praised the service of the sick over all other ministries; he apparently assured the author that "he had received more consolation in this holy exercise than he had ever in the East, while he was in prison, or on the occasion of the shipwreck from which he escaped by miracle."15 Grillot followed Raynaud without reservation in considering death while caring for the sick a true martyrdom, even though he did not adopt Raynaud's theological terms. All these texts point to a common narrative on ministry within the Society of Jesus, particularly in this local context.

The publication of the dissertation also suggests the acceptability of such religious narratives and theological discourses. It was published by a prominent printer, Jacques Cardon (1560-1640), who was active in the field of spirituality and theology, and had strong ties to the Society of Jesus. He published many theological works by prominent Jesuits, for the domestic French market as well as those of Spain and Portugal. A committed Catholic who served in several charitable institutions (the Almonry, the Hôpital de la Charité, and the Hôtel Dieu), he later became a town alderman (échevin) in 1636. Raynaud's Disquisitio also received the necessary approvals by his own superiors, including the local superior provincial Étienne Binet (1569-1639) - with whom he did not get along - and the titular bishop of Damascus, Robert Berthelot (160130 ), a former Carmelite and the suffragan of the then archbishop Alphonse de Richelieu (1582-1653). Berthelot also approved of several of the Jesuit publications circulated in the aftermath of the plague, for instance that of Grillot.

Yet, Raynaud's text has a much broader focus and fits into a wider context. Cardon revealed his own awareness of this context and debate by dedicating the book to the superior general of the Society, Mutio Vitelleschi (1563-1645). Cardon endorsed Raynaud's argument and praised the Society for blessing the church with many martyrs in Europe and the rest of the world. There is also no doubt that the greater Society welcomed such a discourse. In 1658 , the Jesuits published a list of "heroes and victims of charity," which included the names of Jesuits who fitted Raynaud's description, up to the year 1646. It had been composed by the Jesuit bibliographer, Philippe Alegambe (1592-1652), who knew Raynaud when the latter taught in Rome between 1646 and 1651, and continued after his death in $165_{1}$ by János Nadasi (1613-79), the compiler of the litterce апnисе. The book, despite the earlier censure of Raynaud's De martyrio per pestem, was actively supported by the German superior general Goswin Nickel 
(1582-1664) ${ }^{16}$ This insistence on the religious perfection of the commitment to the works of mercy certainly appears to have been an effort to showcase and preserve continuity with the religious ideals of the early Jesuits, at a time when the Society faced an extraordinary level of hostility within the church. It may also have been a way to handle the religious expectations of the many Jesuits who asked, in vain, to be sent as missionaries outside of Europe and on whom the imagination of martyrdom retained a powerful hold. ${ }^{17}$ Finally, it may have proved to be a way to promote a religious ideal that offered a spiritual path to coadjutors. ${ }^{18}$ The publication of an Italian menologium that focused on models of religious heroism among coadjutors may be evidence that the generalate was starting to deal with the social and religious frustrations within the order. ${ }^{19}$ The Heroes charitatis opened by acknowledging the importance of the legislation of Urban VIII (r.1623-44), which regulated the administration of the cult of saints and imposed the specific obligation to abide by the fixed catalog of saints, blessed, and martyrs, in the form of a brief disclaimer consisting of a "protestatio auctoris," which specified that the terms "saints" and "blessed" in the text that followed were not used in the canonical sense as defined by the Holy Office in two decrees of 1624 and $1625 .^{20}$ The work nonetheless pointed to a strong analogy between death through exposure to illness and martyrdom.

16 Philippe Alegambe and János Nadasi, Heroes et Victimce Charitatis Societatis Iesu seu Catalogus eorum qui e Societate Iesu Charitati animam devoverunt: Ad id expositi et immortui peste infectorum obsequio ex charitate, obedientiaque suscepto (Rome: Varesius, 1658).

17 For the case of the French Jesuits, see Guy Laflèche, Les Jésuites de la Nouvelle-France et le mythe de leurs martyrs, in Les Jésuites parmi les hommes aux XVI et XVII e siècles, ed. Geneviève and Guy Demerson, Bernard Dompnier, and Annie Regond (Clermont-Ferrand: Publications de la Faculté des Lettres et Sciences Humaines de l'Université de ClermontFerrand, 1987), 165-95.

18 The Society included two types of coadjutors: temporal coadjutors who did not become priests; spiritual coadjutors who were priests but did not become full members of the order by pronouncing the fourth vow. We know far too little on the history of those members of the Society. See a mention in Liam Brockey, The Visitor: Andre Palmerio and the Jesuits in Asia (Cambridge, MA: Harvard University Press, 2014), 368; the entries "Miembros de la CJ," in Diccionario histórico de la Compañía de Jesús: Biográfico-temático, ed. Charles E. O’Neill and Joaquín M. ${ }^{a}$ Domínguez, 4 vols. (Rome-Madrid: Institutum Historicum Societatis IesuUniversidad Pontificia Comillas, 20o1), 3:2666-67 and, "Coadjutor, Temporal or Spiritual," in The Cambridge Encyclopedia to the Jesuits, ed. Thomas Worcester et al. (Cambridge: Cambridge University Press, 2017), 176-77. All are remarkably ahistorical. This points to a more general lack of attention to the social history of the Society in recent scholarship.

19 Vite di alcuni religiosi di Giesù, scritte da diversi autori e nel volgare italiano: Tradotto da un Religioso della medesima Compagnia (Turin: Gio. Giacomo Rustis, 1664).

20 On this legislation, see Miguel Gotor, I beati del Papa: Santità, Inquisizione e obbedienza in età moderna (Florence: Leo S. Olschki, 2002) and Gotor, Chiesa e santità nell'Italia moderna (Rome: Laterza, 2004), 82-88. 
The similarities between the publication of the Heroes charitatis and that of a catalog of Jesuit martyrs in odium fidei, written by the very same authors, reinforced this analogy. ${ }^{21}$ One suspects that Jesuit librarians would certainly have associated these two works.

What Raynaud therefore contributed in 1630 was an articulate theological defense of a religious ideal that met several of the Jesuits' local and global expectations. In his dissertation, he insisted on the original proximity between the Latin term confessor and the Greek martyr and traced their growing estrangement in the early history of the church. ${ }^{22}$ He browsed through the texts of the fathers and doctors of the church to document the use of the term martyrs in larger and, eventually, metaphorical senses. He noticed, for instance, that Peter Damian $(c .1007-72)$ equated the voluntary practice of flagellation with a form of martyrdom. ${ }^{23}$ By arguing that the heart of martyrdom is patience, Raynaud explored the extension of the term to patience with disease, making Job the greatest example of this type of martyrdom. ${ }^{24}$ By the same token, religious life itself-which Raynaud characterized as "crux quotidiana" (daily cross - -also bears a resemblance to the martyrdom found in the tradition of spiritual literature from early monasticism onward. The vocabulary of martyrdom can also include obedience, chastity, and other virtues that involve sacrifice and suffering. In this sense, martyrdom can be endured by every Christian in their own particular state of life. Indeed, for Raynaud, women suffer "a thousand deaths" in marriage, ${ }^{25}$ yet men (another example of Raynaud's infamous misogyny) suffer even more atrociously. ${ }^{26}$ In the second part of the dissertation, Raynaud turns to the stricter precise sense of martyrdom to explore its conditions. Martyrdom requires a persecutor who acts in odium fidei, it may be manifested in children, but in adults it requires acceptance of death and the intention to die for the faith and true faith alone. He explores the fruits of martyrdom and its affinity with baptism. This part of the treatise is perhaps the more technical as Raynaud discusses the connection between martyrdom and the theological debate on grace. The third part discusses the nature of martyrdom of charity, which Raynaud argues is martyrdom in the stricter sense.

21 Philippe Alegambe and János Nadasi, Annus dierum illustrium Societatis Iesu, sive in anni dies digestce mortes illustres eorum qui ex eadem Societatis Iesu in odium fidei, pietatis, etc. ab impiis occisi, aut veneno necati, vel exilii, carceris, aliisve cerumnis confectu sunt (Rome: Varesius, 1657).

22 De martyrio, 3-7.

23 De martyrio, 3 .

24 De martyrio, $5^{1-57 .}$

25 De martyrio, 121-24.

26 De martyrio, 124-31. 
He does so according to the canons of theological disputation, yet does so in his own, very archeological, style of theology. He acknowledges the weight of authoritative writers as well as the rational arguments that contradict his case. Yet he argues that the evidence of the church fathers supports rather than undermines his views. He insists on the authority of Augustine (354-430) in particular, whom he interprets in his favor. More central to his argument is his exploration of the sensum ecclesiae (sense of the church). He comments on a passage in the Roman Martyrology that refers to a group of priests, deacons and other Christians from Alexandria who died ministering to the sick during the reign of Emperor Valerian (200-260), and states that the church venerates them "velut martyres" (like martyrs) ${ }^{27}$ Raynaud defends the authenticity of this adoration and interprets the "velut martyres" in its fullest sense. He then explores references to these Alexandrian martyrs in the later tradition. He likewise identifies several examples in the history of local churches, running up to the early modern era. He includes several instances of extraordinary magnanimity within the Society of Jesus, characterizing them as cases of true martyrdom, such as the 1628 Lyons plague. To further sustain his argument, he then turns to the Scripture, commenting mostly on passages from the Gospel that encourage sacrifice. He dismisses the argument of the silence of the church fathers on a martyrdom of charity as, precisely, an "argumentum ex silentio" (argument from silence). He argues that it is no surprise that the church fathers focused on the type of martyrdom they were witnessing, while barely mentioning another form of martyrdom uncommon in their time. ${ }^{28}$ The strongest argument against Raynaud's opinion was, of course, the absence of violence against the body of Christ or against the faith in such instances of charity. ${ }^{29}$ To address this, he tries to disconnect direct violence and martyrdom by arguing that some martyrs were not the object of direct violence (such as some virgins who cast themselves from precipices or into rivers to defend their chastity). God, Raynaud argues, does not look to the violence itself, or to the wickedness of the persecutors, but rather to the faith of the martyrs and their conformity with Christ's example, particularly in welcoming suffering. He also

27 "Alexandriæ commemoratio ss. Presbyterorum, Diaconorum, et aliorum plurimorum, qui tempore Valeriani Imperatoris, cum pestis sævissima grassaretur, morbo laborantibus ministrantes, libentissime mortem oppetiere, quos velut martyres, religiosa piorum fides venerari consuevit," quoted by Raynaud, De martyrio, 412.

"Hoc enim est martyrium frequentissimum, et quo tempore Patrum plerique scribebant, quotidianum. Eamque ob causam, videtur antonomastice dictum esse martyrium. Cum e contra, hoc martyrium pro quo pugnamus, sit admodum infrequens, et interdum vix in pluribus seculis alicubi locum habeat," De martyrio, 482.

De martyrio, $483-87$. 
dismisses the argument that an explicit confession of faith is lacking in a martyrdom of charity. The sacrifice of those who honor Christ by risking their lives in the service of others is in itself a testimony of faith. ${ }^{30}$ The last section of the book then demonstrates that the virtues displayed by both types of martyrs are actually the same: both display extraordinary faith, hope, and charity; both must summon extreme perseverance and fortitude, and may fall to their ruin or that of others; and both possess the same degree of resemblance to Christ, the only true martyr who died out of love for humanity.

The book therefore shows a willingness to bring together theologies of martyrdom and ministry, along with the fluidity of doctrine in early modern Catholicism, by contrasting diverging opinions, as long as these opinions abided by the formal rules of the sacra doctrina (sacred doctrine). ${ }^{31}$ It was on the same terms that the Inquisition would later challenge Raynaud's explicit and determined attempt to overhaul the established canonical definition of martyrdom.

\section{The Censure of the De martyrio per perstem}

When the De martyrio per pestem came under the suspicion of the Roman Inquisition, Raynaud was not exactly unknown to the inquisitors. In the 163os, he was becoming increasingly famous on Europe's theological scene. Besides, the censure of his treatise on martyrdom was part of a wider "affair" centered on the singular figure of a Minim Friar, Nicolas Chichon (1580-1646), a French who had fled to Rome. Although the debate has left few traces in the historiography of early modern Catholicism, and ultimately had but a marginal impact, it occupied the Roman Inquisition for more than a decade. ${ }^{32}$ This case was

30 De martyrio, $493-94$.

31 On doctrine as content and form, see Philippe Büttgen's introduction to Philippe Büttgen, Ruedi Imbach, Ulrich J. Schneider, and Herman J. Selderhuis, Vera doctrina: Zur Begriffsgeschichte der Lehre von Augustinus bis Descartes: L'idée de doctrine de saint Augustin à Descartes (Wiesbaden: Otto Harrassowitz, 20o9) and Büttgen, "Le contraire des pratiques: Commentaires sur la doctrine de Michel de Certeau," in Lire Michel de Certeau: La formalité des pratiques - Michel de Certeau lesen; Die Förmlichkeit der Praktiken, ed. Philippe Büttgen and Christian Jouhaud (Frankfurt am Main: Vittorio Klostermann, 20o8), 69-98.

$3^{2}$ On Chichon, see Jean-Louis Quantin, "Philologie et querelle de la grâce au XVII ${ }^{\mathrm{e}}$ siècle: Sirmond, Valérien de Cimiez, et le Saint-Office," in Amicorum societas: Mélanges offerts à François Dolbeau, ed. Jacques Elfassy, Cécile Lanéry, and Anne-Marie Turcan-Verkerk (Florence: SISMEL-Leo S. Olschki, 2013), 699-739, and Jean-Pascal Gay, "Histoire de censures inversées: Nicolas Chichon, Suárez et Saint-Office (1624-1637)," in Hétérodoxies croisées: Catholicismes pluriels entre France et Italie, $X V I^{e}-X V I I^{e}$ siècles, ed. Alain Tallon and Gigliola Fragnito (Rome: École Française de Rome, 2015), 323-45. 
itself part of the back-and-forth that followed the de auxiliis congregations. It was one more example of the contending theological factions' attempts to either build on or undermine the official status quo that resulted from Pope Paul V's (r.1605-21) decision to silence the debates. In the early days of the pontificate of Urban VIII Barberini (r.1623-44), the fears raised by some Dominicans about his election were still fresh as he displayed the first signs of favoring the Society of Jesus. The Inquisition's single-minded focus on the case of the French Minim can be seen, among other things, as an attempt to undermine the Jesuits' position.

In 1624, Chichon was introduced to Cardinal Desiderio Scaglia (1567-1639) and then to the Inquisition by the Dominican Costantino Testi (1583-1637), shortly before he himself became the socius of the Commissary of the Holy Office. Recommended to Testi by the Minim General as an "eminent theologian," Chichon is one of the many figures who, from the early seventeenth century onward, sought to advance their theological careers by turning their expertise as controvertists (ad extra in the controversy with Protestantism) into that of controversialists (ad intra in the controversies between Catholics). ${ }^{33}$ Convinced that God called on him to denounce the "domestic errors that abound" in France, ${ }^{34}$ Chichon particularly targeted the Jesuits and their doctrine of grace. He believed he had identified (or been mystically inspired to see) a series of errors in the works of Francisco Suárez (1548-1617). Therefore, he asked Testi for permission to censure the Jesuit theologian, whose De gratia had recently been published. Chichon attributed the work, sincerely or not, to a pseudo-Suárez, stating that he could not "believe that such manifest errors could have emerged from Fr. Suárez's pen." The Inquisition quickly seized the opportunity and in November 1624 wrote to Chichon asking him to transmit the list of errors he had identified in the De gratia. ${ }^{35}$ By mid-1625, Chichon was in Rome and had his first audience with the theologians deputed by the Inquisition in July. ${ }^{36}$

Encouraged by the warm welcome he had received, Chichon started questioning Jesuit works and theologians more and more. In the autumn of 1625, he provided the congregation with a memorandum against Gennadius of

33 Quantin quotes Alphonse Dupront on the inward turn of heresiological anxiety: Jean-Louis Quantin, "Philologie et querelle de la grâce au xvii siècle"; see Alphonse Dupront, "Réflexions sur l'hérésie moderne" [1967], in Genèse des temps modernes: Rome, les Réformes et le Nouveau Monde, ed. Dominique Julia and Philippe Boutry (Paris: Gallimard, Le Seuil, 2001), 113-21. Archivio della Congregazione per la Dottrina della Fede (ACDF), S.O., Censurce Librorum 1607-1625, 704 .

35 Decretum of November 24, 1624, ACDF, S.O., Censurae Librorum 1607-1625, 697.

36 Decretum of July 23, ACDF, Decreta 1625. 
Massilia (d.496) and Valerian of Cimiez (d.46o), whose works he denounced as semi-Pelagian. ${ }^{37}$ This claim not only picked up the heresiological vocabulary and characterizations used against the Jesuit theology of grace after Luis de Molina (1535-1600), but it was also a direct attack on the French Jesuits, and particularly on Jacques Sirmond (1559-1651). Sirmond had edited homilies and letters on monastic life that he attributed to Valerian, the fifth-century bishop of Cimiez. ${ }^{38}$

The two causes, of Valerian and Gennadius on the one hand, and of Suárez's alleged errors on the other, progressed in tandem until Chichon's first dismissal at the end of September 1626. Meanwhile, Sirmond had no doubt been informed by Terenzo Alciati (1570-1651), the voice of the Society in the 1620 s Inquisition, before being officially notified by order of Urban VIII, and through the intermediary of Vitelleschi, of the examination of Valerian's letters by the Holy Office. He had been able not only to respond to the merits but also to build a real strategy to defend his edition of Valerian. He was therefore responsible for Raynaud's involvement in the dispute-at least according to the latter's account of his own intervention. ${ }^{39}$ At the time, Raynaud held the chair of Scholastic theology in Lyons' Trinity College. In 1628, he gave Sirmond a full-fledged answer to Chichon's claims against Valerian, both on theological and philological grounds. ${ }^{40}$ Before it became public in $1632,{ }^{41}$ Chichon obtained knowledge of Raynaud's answer and complained to the Inquisition. ${ }^{42}$ Back in Rome in 1632, after having escaped his province, Chichon focused on Raynaud's pamphlet against him. In 1633, the congregation, with Scaglia still acting occasionally to support Chichon, askedVitteleschi to suppress Raynaud's Contra criminatorem minimum (Against a Minim slanderer). ${ }^{43}$ When the Index deferred the De martyrio per pestem to the Inquisition in December $1633,{ }^{44}$ to

37 ACDF, S.O., Censurae Librorum 1607-1625, 704-705, appendix 1 in the article by J.-L. Quantin.

38 Jacques Sirmond, Sancti Valeriani episcopi Cemeliensis homiliae xx: Item Epistola ad Monachos, de virtutibus et ordine doctrinae Apostolicae; Omnia nunc primum, praeter unicam Homiliam, post annos plus minus mille ducentos in lucem edita (Paris: Sebastianus Cramoisy, 1612).

39 Théophile Raynaud, Syntagma de Libris propriis, in Opera omnia: Apopompceus, 20 vols. (Kraków: Annibal Zangoyski, 1669), 20:29.

40 Jean-Louis Quantin, "Philologie et querelle de la grâce au xviie siècle."

41 [Théophile Raynaud], Valerianus Cemeliensis Episcopus, integer doctrinae, labisque purus: Disquisitio Theologica, Qua Massiliensium, siue Semipelagianorum error circa salutis initium, accurate excutitur; Et Parcus Charitatis, Valeriani criminator, repellitur (Lyon: Claudius Landry, 1632).

42 ACDF, S.O., Censurae Librorum 1607-1625, 724, 738.

43 ACDF, S.O., Decreta 1633, 15 o.

44 ACDF, S.O., St. St. O1 a, dossier 18, 137. 
be censured in June $1634,{ }^{45}$ the connection between the two causes must have been apparent to all, all the more so because the theology of martyrdom was clearly linked to that of grace. Raynaud would always regard it, first and foremost, as a political censure of himself and the Society.

Yet, there remained something specific to the discussion of martyrdom itself in the Inquisition. At this stage in the history of the relationship between the Holy Office and the Index, it was still rare for the Inquisition to take up condemnation of a work to the detriment of the authority of the Index. To justify this, the congregations included the discussion of other similar texts, namely Bellum divinum (Divine war) by Filiberto Marchini (1586-1636), a Barnabite from Novara, published in Florence in $1633,{ }^{46}$ and a discorso titled Glorioso trionfo d'invitta morte di carità, emulatrice di vero martirio (The glorious triumph of unconquered death out of charity emulating true martyrdom) written by a Camilian Friar, Francesco Antonio Sarro, and published in Naples in $1632 .{ }^{47}$ The theologians of the Index also composed a list of four propositions they asked the Inquisition to assess and qualify. It is no surprise that orders such as the Barnabites, whose founder emphasized the works of mercy above all, and the Camillians, who dedicated themselves to the ministry of the sick, promoted a redefinition of martyrdom that satisfied their own particular religious focus. The censorship of these two other works also shows that there was no absolute connection between the censure of the De martyrio per pestem and Chichon's case. Marchini's Bellum divinum was reported to the Roman Inquisition by Brother Tommaso Caccini (1574-1648), who denounced the "dottrine nuove intorno al sacramento dell'estrema uncione" (new doctrines on the sacrament of the extreme unction) ${ }^{48}$

While Raynaud's text thus certainly reflected a wider discussion, Marchini's and Sarro's discourses were not very original. For their theological argumentation, they relied heavily on the 1630 De martyrio perpestem. That the Inquisition deliberately targeted Raynaud's treatise is quite clear. The four propositions set apart by the Index theologians ${ }^{49}$ can be summed up as follows:

45 ACDF, Ind., Protocolli II, 125.

46 Filiberto Marchini, Bellum divinum effuse ac diligenter explicatum (Florence: Sermartelliana, 1633).

47 Francesco Antonio Sarro, Glorioso trionfo d'invitta morte di carita, emulatrice di vero martirio: Discorso nel quale al vivo si dimostra la molta somiglianza ch'é frà la morte de Santi Martiri, et di coloro, ch'in serviggio dell'appestati per la Carita Christiana muoiono (Naples: Aegidius Longus, 1632).

48 ACDF, Ind., Protocolli II, 133, letter 23 avril 1633, 134, letter 20 août 1633, 135, 3 September 1633 letter of Tomasso Caccini to the Holy Office.

49 ACDF, S.O., St. St. o1 a, 137. 
1. Dying as a result of endangering one's own life for the physical or spiritual salvation of one's neighbor deserves the name of martyrdom.

2. A martyrdom of charity goes beyond bloody martyrdom in that it displays greater charity toward one's neighbor.

3. This martyrdom merits the same benefits as bloody martyrdom.

4. Martyrdom with the intention of defending a pious doctrine (such as that of the immaculate conception of the Virgin Mary) is also true martyrdom.

Every proposition came with a reference to a passage by Raynaud. The other authors were only mentioned as supporting the doctrine of propositions one to three. Many of the theologians in charge of examining the propositions played a part in the cases brought by Chichon, which were endorsed by the Dominicans. The group of censors included Niccolò Ridolfi (1578-1650), master of the Dominican Order since 1629; Niccolò Riccardi (1585-1639), master of the Sacred Palace; Vincenzo Maculani (1578-1667), commissary of the Holy Office, Domenico Campanella (1581-1663), general procurator of the Carmelites; and, finally, a Cistercian, Ilarione Rancati $(1594-1663) .{ }^{50}$ The group was staunchly Augustinian and largely anti-Jesuit, though their positions would later diverge after the condemnation of Cornelius Jansenius's (1585-1638) Augustinus. ${ }^{51}$ All agreed on the censure of Raynaud, while a few other theologians, particularly the Jesuit Alciati, argued against it or in favor of a milder form of censure.

On July 27, the pope granted the censure to the Holy Office. Yet, he left the propositions untouched and prohibited the De martyrio itself instead. The decree was meant to instruct the Society, the nuncio in France, and the inquisitors in Italy to act in order to suppress it. ${ }^{52}$ Yet, it appears that the censure was not published at the time. ${ }^{53}$ The Jesuits, as well as possibly the Barberinis, may have intervened either to protect Raynaud or his theological thesis. In 1662, Raynaud would return to the episode in his scathing and notorious denunciation of the politicization of the process of censorship under the Dominicans (De immunitate authorum Cyriacorum a censura [Of the immunity of the Cyriac authors from censure]). ${ }^{54}$ Raynaud even argued that the cardinal-bishop of Lyons, Alphonse de Richelieu, the French ambassador in Rome (possibly on

$5^{\circ}$ List of qualificators in ACDF, S.O., St. St. o1 a, 139.

$5^{1}$ Jean-Louis Quantin, "Philologie et querelle de la grâce au xviie siècle"; Orietta Filippini, "Verso Roma locuta: Questioni teologiche, corte madrilena et Santa Sede alla metà del Seicento," Roma moderna e contemporanea 1-2 (2010): 231-73.

$5^{2}$ See the copy of the decree in ACDF, Ind., Protocolli II, 126.

53 ACDF, Ind., Protocolli KK, 371.

54 [Théophile Raynaud], De Immunitate Authorum Cyriacorum a censura (Rome [= Lyons?]: n.p., 1662), 201. 
the order of the other Richelieu), as well as the ambassador of Savoy (with whose princely family Raynaud had strong connections), had acted together in order to suspend the censure. Indeed, Raynaud's thesis would be defended, and the censure challenged, on several grounds and through different strategies.

\section{Defending the De martyrio per pestem}

The issue came under new scrutiny in 1646, in a different theological, ecclesial, and political context, but also at another time in Raynaud's life. The Jesuit theologian had come to Rome as professor of Scripture at the Collegio Romano, a position he owed to the protection of the Barberinis. ${ }^{55}$ It was hardly convenient for the Society to have a man whose works were under suspicion as a professor in their most important college in Europe. Raynaud got the Inquisition and Index to discuss the corrections that were needed to make his censured works palatable (his Error popularis de communione pro mortuis [Popular mistake about Communion for the dead] and the work he regarded as the most important for his ministry as a theologian, his Heteroclita spiritualia [Spiritual abnormalities]). While the congregations of the Inquisition and the Index tried to avoid stating requirements for correction, Raynaud had strong support outside the congregation. The theologians of the Index managed to postpone their decision until March 1649. While firmly hostile to Raynaud's Error popularis, they relented slightly on the De martyrio. They nonetheless maintained that Raynaud ought to retract his opinion that a martyrdom of charity could grant forgiveness for one's sins ex opere operato (from the deed performed), as true martyrdom did. They also continued to regard as justified their refusal to consider dying in defense of a pious doctrine as worthy of being called martyrdom. ${ }^{56}$

Pressure on the congregation steadily mounted. The Barnabites joined the fray again and asked that Marchini's book be freed from censure along with Raynaud's. ${ }^{57}$ In February 165 o, a congregation met under the supervision of Bernardino Spada, a cardinal who firmly defended Raynaud's position. ${ }^{58}$ The theologians handed down their proposed revisions, but Raynaud's adversaries

55 Raynaud was clearly part of the cultural and religious network that surrounded the Barberinis that Peter Rietbergen has described, see Rietbergen, Power and Religion in Baroque Rome: Barberini Cultural Policies (Leiden: Brill, 2006).

56 ACDF, Ind., Protocolli II, 123.

57 ACDF, Ind., Diari IV, 316.

$5^{8}$ ACD F, Ind., Diari IV, 345 . 
managed to prevent a decision..$^{59}$ Problems remained with Raynaud's other works and, in the meantime, the hotheaded theologian had provoked the Inquisition once more by allowing his Hoploteca contra ictum calumnice (Collection of weapons against the blow of calumny) to be published in Lyons. This theological treatise on calumny was a clear indictment of Raynaud's censors. ${ }^{60}$

The issue resurfaced again in 1659 . By that time, Raynaud was back in Lyons and had become a prominent theological figure of great authority within the Society, on the theological scene at large and among scholars. He was moreover preparing the edition of his Opera omnia, with both the support of his province and of the Jesuit Roman Curia. Shortly prior to this, he had entered into a fiery controversy with Tomás de Hurtado (c.159o-1659), a Spanish theologian, Caracciolino and engaged Banesian, who had debated several of Raynaud's contested works. In 1655, Hurtado published an attack on several of Raynaud's positions, particularly his thesis on martyrdomin hisResolutiones orthodoxo-morales, scholastica, historicce de vero, unico et proprio martyrio fidei (Orthodox and moral as well as scholastic and historic resolutions on the true, one and proper martyrdom) ${ }^{61}$ Raynaud swiftly replied in 1656 , with his pseudonymous Theologia antiqua de vera martyrii adcequate sumpti notione (Ancient theology on true martyrdom), ${ }^{62}$ which Hurtado answered with his Antidotum duplexcontra duplex venum (Double antidote against a double venom). ${ }^{63}$ Both Hurtado's and Raynaud's works were deferred to the Index, possibly in late 1657 , and examined in early $1658 .{ }^{64}$ Raynaud then acted through Honoré Fabri (1608-88), one of the most prominent Jesuits on the Inquisition at the time. He sent a

59 ACDF, Ind., Protocolli KK, 371.

60 Théophile Raynaud, Hoplotheca contra ictum calumnice (Lyons: Borde, Philippe et Arnaud, 1650).

61 Tomás Hurtoda, Resolutiones orthodoxo-morales, scholasticae, historicae de vero, unico et proprio martyrio fidei sanguine sanctorum violenter effuso rubricato, adversus quorundam kainologian de proprio martyrio charitatis et misericordiae, quibus junguntur digressiones de germana intelligentia quorundam canonum Illiberitani concilii, de variis tormentorum instrumentis et de martyrio per pestem, de chori ecclesiastici antiquitate, necessitate et fructibus, de coronis et tonsuris gentilitatis, synagogae et christianismi, de religione Nazaraeorum, de restrictione mentali (Cologne: Cornelius ab Egmond, 1655).

62 Theologia antiqua de vera martyrii adaequate sumpti notione, ad spumosam Kainologian et fragosum Taratantara Thomae Hurtado Buccaferei de Seir iterato vulsi ac depilati a Leodegario Quintino Heduo S.T.D. (Lyons: Antonius Iullierion et Antonius Baret, 1656).

63 Antidotum duplex contra duplex venenum, quod ex fonte Theophylino ebibit Leodegarius Quintinus Heduus, propugnante D. Didaco Sanchez del Aquila, doct. theologo (Seville: Iohannes de Ribera, 1657).

64 ACDF, Ind., Protocolli KK, 672, 676. 
supplication to the Inquisition, which again agreed to discuss the corrections that might make his position on martyrdom more acceptable. ${ }^{65}$

The commission discussing the matter included Giovanni Bona (16o9-74), who, though no ally of the Jesuits, appreciated Raynaud's erudite brand of theology. ${ }^{66}$ But the commission also included several familiar and potential adversaries of the Jesuit theologian, such as Michelangelo Ricci (1619-82) and Ilarione Rancati. The latter, in particular, had played a significant role in opposing several of Raynaud's works, including the 165 o holdup of the proposed revision of the De martyrio per pestem. The commission granted a list of possible revisions that allowed Raynaud and his publisher to prepare an amended version of his previously censured works. Raynaud and his publisher included this new version of the De martyrio in the eighteenth volume of the Opera omnia, which compiled several of Raynaud's polemical works. The congregation had asked that Raynaud change his title from De martyrio per pestem ad martyrium improprium et proprium vulgare comparato (Of martyrdom by plague compared to improper and proper martyrdom as commonly understood) to De martyrio per pestem ad martyrium improprium et proprium Ecclesiasticum comparato (Of martyrdom by plague compared to improper and proper martyrdom as understood by the church). It also asked that the decisive third part of the work end with a long addition in which Raynaud acknowledged (1) that his defense of the use of the term martyr for those who had endangered their lives out of charity did not mean that the term, in this context, had the same meaning that the Catholic theological tradition ascribed to martyrdom, and that only those who fitted the traditional tenets of martyrdom deserved to be ritually celebrated as martyrs; (2) that martyrdom in resistance to persecution enclosed a greater testimony of faith; and (3) that his thesis regarding the ex opere operato effects of such a martyrdom had no certainty and remained merely probable. ${ }^{67}$ The commission also maintained its opposition to the idea

65 See Biblioteca Apostolica Vaticana (BAV), Chigi H I 21, 242.

66 Jean-Louis Quantin, "Protecteur et censeur: Giovanni Bona et la culture religieuse gallicane," Rivista di storia e letteratura religiosa 3 (2010): 533-78.

67 "Haec sunt, quæ pro commendanda charitate eorum, qui inter ministrandum Peste contactis vitam amittunt, dicenda occurrunt: cui chiartati, qua maior adversus proximum nulla est, cum propter Deum impenditur, eximiæ fortitudinis, et martyrii nomen convenit, non tamen in ea acceptione, qua patres doctores, et Ecclesia vocant illos, qui in pugna et certamine cum Tyranno propter Deum vitam non resistentes ponunt suntque magis explicite et formaliter testes, et ideo per excellentiam, sive antonomastice martyres appellantur, qui soli cultum martyrum in Ecclesia obtinuerunt, et martyrum nomine in acceptione apud Ecclesiam hactenus usitata censentur, illi privilegio hoc gaudent, ut gratiam ex opere operato consequantur, et ab omnis pœnæ reatu absolvantur, quod privilegium ad istos non 
that dying in defense of a pious doctrine could be considered martyrdom. As for the revisions that were asked of him, Raynaud would shortly, in a volume that wrapped up his complete works and was published under a pseudonym, expose the revisions as revisions, leaving his readers free to make their own judgment. ${ }^{68}$

The volume in which he had planned to do this included not only his pamphlet against Hurtado and in defense of the De martyrio (the Theologiam antiquam de vera martyrii notione) but also an Apologia de martyrio per pestem (Defense of martyrdom by plague), written in 1650 by João de Andrade, a Portuguese Trinitarian friar and teacher of theology. ${ }^{69}$ Again, it is no surprise that a member of a religious order whose religious life centered on the works of mercy would have openly supported a thesis such as Raynaud's. Andrade did so firmly. He acknowledged Raynaud's thesis either as true or at least as probable and free from censure. Andrade did so in a more Scholastic style of theology than Raynaud. He browsed through the corpus of theological treatises, to determine that martyrdom was not restricted to "immediate" death in defense of orthodox faith but could include offering of one's life for other supernatural virtues. He also detailed, more than Raynaud had, all the conditions that theologians did not require for true martyrdom (particularly regarding persecution and persecutors). This enabled him to advocate a broader understanding of martyrdom. To Andrade, martyrdom of charity fit the common theological definition of martyrdom as the offering of one's life to testify to the truth or in an extraordinary display of virtue. He seems to have been convinced by Raynaud's liturgical example of the Alexandrian martyrs. He insisted, in particular, that Raynaud's thesis could not be deemed anything less than probable. He discussed in detail every possible theological qualification. The proposition could not be deemed heretical, or even erroneous, since the opposite conclusion lacked the marks of theological certitude. Nor was it hæeresim sapiens, male sonans or offensive to pious ears. It could not be regarded as scandalous, because it could not lead to the ruin of souls in any way. It was not even reckless (temeraria), as it did not lack authority. Finally, Andrade insisted on the impossibility of dismissing it as novitas. In what is perhaps one of the most intriguing and innovative parts of the Apologia, ${ }^{70}$ Andrade argues that if

ea probabilitate extendi potest, quoad illos quos neque certum et aut extra controversiam, sed probabile tantum hoc privilegio gaudere": Raynaud, Opera omnia, Polemica, 18:501.

68 For those revisions of the De martyrio, see Raynaud, Opera omnia, Apopompceus, 20:256.

69 Raynaud, Apopompceus, 219-44.

70 Raynaud, Apopoтрсеиs, 235. 
Raynaud's opinion was a novelty, then the most theologically significant developments of the sixteenth and seventeenth centuries, particularly the many propositions put forward in Coimbra, with a clear reference to the discussions of grace, would also have been novelties.

The Apologia was clearly written as part of a concerted effort to defend Raynaud during his 1650 bid to have the censure of his book cancelled or at least revised; hence the insistence on the impossibility of issuing any note of censure against the book. The Apologia was circulated around Portugal and signed by forty-eight theologians. A few added their own elaborate theological discourse in support. ${ }^{71}$ Among those, there were, of course, several Jesuits, including for instance Martim Leitão, who would later work as the reviewer for the assistancy of Portugal, and many Jesuit professors of theology in Évora, Coimbra, and Lisbon (including those teaching at the Irish college). But the list also included theologians from several other religious orders, including Benedictines, Cistercians, and Carmelites, as well as a small number of secular clergymen (such as a doctor from Coimbra and dean of the diocese of Lisbon Andreas Hurtado de Mendoça). Among the signatories was Louis Poinsot, another Trinitarian, who held the Scotist chair of theology in Coimbra (the so-called cathedra Durandi). The Apologia was meant to look as universal as possible, but succeeded only partially. This also reveals part of the rationale of the Apologia: it was not only a strong rejection of the censure of Raynaud's thesis, it was also a clear indictment of the Inquisition's censure as evidence of a provincial mentality in Rome as well as, and perhaps most of all, a predominantly Dominican partisan enterprise.

Raynaud would later continue arguing along the same lines. Shortly after he obtained the right to publish a revised version of his censured books, he published his infamous pamphlet De immunitate authorum Cyriacorum a censura, which argued that the monopoly of the Dominicans over the Index and the Inquisition had skewed the entire process of censorship within the Catholic Church. ${ }^{72}$ He kept returning to the specific censure of his De martyrio per pestem. Mentioning the condemnation of Marchini's Bellum divinum, he even went as far as to say that if the Dominicans rejected this doctrine it was because they were much less devoted to the care of the sick than other

71 See, for instance, the one by José de Brito, from Évora, in Raynaud, Apopompceus, 242-43.

72 On Raynaud's criticism of Roman censorship, see Marco Cavarzere, La prassi della censura nell'Italia del Seicento: Tra repressione e mediazione (Rome: Edizioni di Storia e Letteratura, 2011). 
religious orders. ${ }^{73}$ Further on, he provided an account of the history of the censorship of the text, imputing full responsibility to the actions of the secretary of the Index. ${ }^{74}$

By reacting to the Roman censorship of a martyrdom of charity-and in reality in reaction to this censorship alone-Raynaud challenged the exclusive right of Roman congregations to define questions of faith and even to censure theological works. He constantly invoked the alleged universal approval of his doctrine that could only render the censure suspect of having been composed ad hoc, and therefore of having no authority other than that of the private authority of those who promoted it. In 1662, he wrote:

This is how the thing was handled in Rome by the artifice of the Dominicans. But it has been seen otherwise all over Europe. As a matter of fact, over two hundred eminent theologians, from Portugal, Spain, France, Belgium, Germany, Poland, Lithuania, and Italy, as well as many erudite prelates and twelve famous academies have affirmed the truth by their signature. It is in vain that Marini has made his vulgar efforts to swart it, fuming in confusion, only succeeding in revealing the value of the first judgment for what it is: trash. ${ }^{75}$

The publication of Andrade's Apologia served to back up these claims. Raynaud's gesture also points to the complexity of what can be called a geography of early modern theological authority. The contemporary imagination of modern Catholicism tends to erase this complexity. In the 16oos, it remained possible to regard the authority of theologians as greater than that of Roman congregations.

73 "Itaque primum liber liber ille de bello divino, curantibus Cyriacis proscriptus est, et carbone notatus; cum tamen omnium Doctorum Iudicio, sit liber bonus, et suo genere optimus, grata doctrinæ varietate apscens lectorem, et in tempore necessitatis peropportunus. Sed hanc necessitatem non multum attendunt Cyriaci; nec volunt librum sibi esse usui in illa tempore. Nam proxime superioribus annis, grassante in tot Provinciis pestilentia, multi passim auditi sunt FF. Minores, Capucini præsertim ac Recollecti, in eo pio officio defuncti; multi item Iesuitæ, et aliquorum aliorum ordinum: Cyriacorum vix ulli": De Immunitate Authororum Cyriacorum a censura, 190.

74 De Immunitate Authororum Cyriacorum a censura, 201-3.

75 "Res artificio Fratrum [i.e., the Dominicans], sic gesta in urbe. Sed universæ Europæ aliter visum. Nam Theologi insignes ultra ducentos, ex Lusitania, Hispania, Gallia, Belgio, Germania, Polonia, Lithuania, Italia; Antistites item lectissimi non pauci; et Academiæ celebres duodecim, astipulatione sua firmavere veritatem; nequicquam emotis eam ob rem feris fluctibus Marinis, despumantibus confusiones suas; et detritum priorum Iudicium honorem causantibus": De Immunitate Authorum Cyriacorum a censura, 203. 


\section{Conclusion}

This debate, and the back-and-forth over a theological opinion with strong connections to religious ideals, may be significant for the history of the Society of Jesus as well as for that of early modern Catholicism.

Firstly, it reminds us of several shifts in the history of spirituality and their connections to more institutional and demographic trends. While martyrdom may have remained a goal on the horizon for several Jesuits, it was also a distant horizon for many who were refused missions or who belonged to provinces where occasions for martyrdom were scarce, particularly at a time when religious conflict started to wane. A desire to reorient religious aspirations and vocational narratives was certainly understandable at a time when demographic, social, and institutional evolutions within the Society of Jesus brought the question of the place of the coadjutors within the Jesuit structure to the forefront.

Secondly, it reminds us that early modern narratives may have a stronger hold on modern and contemporary Catholicism than is sometimes acknowledged. There is clear evidence that a tradition survived within the Society of a martyrdom of charity, and that contemporary evolutions in the theology of martyrdom have drawn on such traditional narratives. In 1814, the newly restored Jesuit curia promoted a work of propaganda by Ramón Diosdado Caballero (1740-1829 or 1830), titled Gloria posthuma Societatis Iesu (Posthumous glory of the Society of Jesus), which recounted the history of the order, the adverse effects of the suppression, and the good deeds performed by Jesuits and ex-Jesuits before and after 1773. Caballero discussed the deaths of ex-Jesuits during the 1800 plague in the Basque country and acknowledged them as "martyrium charitatis." ${ }^{76}$ Clearly, the narrative and tropes survived the eighteenth century and the suppression. Such narratives and shared religious ideals fostered corporate alliances within early modern Catholicism. Like-minded orders flocked around the Jesuits, and the Jesuits acted - theologically and politically — as the spearhead of a coalition dedicated to promoting this religious ideal.

Finally, debates and conflicts within early modern Catholicism had already become remarkably politicized. Paolo Broggio has convincingly shown that the de auxiliis congregations exposed and contributed to a process of politicization

76 Ramón Diosdado Caballero, Gloria posthuma Societatis Iesu (Rome: Franciscus Bourlié, 1814), Pars prima, 39. 
within early modern Catholicism. ${ }^{77}$ Yet, this politicization may have been a far stronger and wider phenomenon than what Broggio has described. ${ }^{78}$ While the debate over martyrdom did have some connections to the theology of grace, this theological issue was not central to the debate between the Jesuits and their adversaries. The connection here is more political than theological. Those who opposed the Jesuits on other grounds also opposed them on martyrdom of charity. Those who supported the Jesuits on this issue, because of its specific religious overtones, also often supported the Jesuits on the issue of grace. Blocs were being formed and were already in the making sometime before the 165 os. $^{79}$ This was a real and very early polarization within early modern Catholicism. It is no surprise that such a potent phenomenon was apparent to a man like Raynaud, whose work and life were embedded in this polarization. Indeed, for him, it was just another occasion to do one of the things he liked best: paint himself as a martyr.

77 Paolo Broggio, La teologia e la politica: Controversie dottrinali, Curia romana e monarchia spagnola tra Cinque e Seicento (Florence: Leo S. Olschki, 20o9).

78 Building on de Certeau's "formalité des pratiques," I have argued (Jean-Pascal Gay, Jesuit Civil Wars: Theology, Politics and Government under Tirso González [Farnham: Ashgate, 2012])] that this politicization also went far beyond the influence of political institutions and parties on theological debates.

79 A phenomenon Anthony D. Wright has described in the case of French Catholicism in The Divisions of French Catholicism: The "Parting of the Ways" (Farnham: Ashgate, 2011). 